\title{
Pectin Methylesterase Activity Assay for Plant Material
}

\author{
Kerstin Mueller ${ }^{1}$, Sebastian Bartels ${ }^{2}$ and Allison R. Kermode ${ }^{2^{\star}}$
}

\author{
${ }^{1}$ Biological Sciences Department, Simon Fraser University, Burnaby, Canada; ${ }^{2}$ Institute of Botany, \\ University of Basel, Basel, Switzerland \\ *For correspondence: kermode@sfu.ca
}

[Abstract] Homogalacturonans, the most abundant pectins of the plant cell wall, can be methylesterified at the C-6 position of the galacturonic acid residues. Demethylesterification of cell wall pectins is catalyzed by apoplastic pectin methylesterases (PMEs). Several plant developmental processes and plant-environment interactions involve PME-mediated cell wall modification, as it promotes the formation of $\mathrm{Ca}^{2+}$ cross-links along the stretches of the demethylesterified galacturonic acid residues (Wolf et al., 2009; Müller et al., 2013), and thus influences the biophysical properties of plant cell walls. Here, we describe a protocol that can be used to estimate the activity of PMEs in a total soluble protein extract from plant or seed tissues. Soluble protein is extracted from the plant/seed materials, and a coupled enzyme assay is performed, according to a procedure modified from Grsic-Rausch and Rausch (2004). The methanol released from methylesterified pectins as a result of PME activity is oxidized to formaldehyde by alcohol oxidase. The formaldehyde is then used as an electron donor by formaldehyde dehydrogenase to reduce NAD+ to NADH. The formation of NADH from NAD+ is followed spectrophotometrically, and used to estimate the PME activity in the protein extract.

\section{Materials and Reagents}

1. Arabidopsis thaliana plant or seed materials

2. Liquid nitrogen

3. $100 \mathrm{mM}$ sodium phosphate buffer $(\mathrm{pH} 7.5)$

4. $0.5 \%(\mathrm{w} / \mathrm{v})$ Pectin (in $\mathrm{dH}_{2} \mathrm{O}$ ) (Sigma-Aldrich, catalog number: P-9135)

5. $0.1 \mathrm{U} / \mu \mathrm{l}$ Alcohol oxidase (in $100 \mathrm{mM}$ phosphate buffer) $(\mathrm{pH} 7.5)$ (Sigma-Aldrich, catalog number: A2404)

6. $0.5 \mathrm{U} / \mu \mathrm{l}$ Formaldehyde dehydrogenase (in $100 \mathrm{mM}$ phosphate buffer) ( $\mathrm{pH} 7.5$ ) (SigmaAldrich, catalog number: F1879)

7. $0.4 \mathrm{mM} \mathrm{NAD+}$ (in $100 \mathrm{mM}$ phosphate buffer) (pH 7.5) (Sigma-Aldrich, catalog number: N8410)

8. PME from orange peel (Sigma-Aldrich, catalog number: P5400) 
9. Protease inhibitor cocktail (1x) (contains $100 \mathrm{mM}$ PMSF, $2 \mathrm{mM}$ Bestatin, $0.3 \mathrm{mM}$ Pepstatin A, and 0.3 mM E-64) (abmGood, catalog number: G135)

10. Protein extraction buffer (see Recipes)

11. Master mix (see Recipes)

\section{Equipment}

1. Eppendorf tubes

2. Mortar and pestle

3. Vortexer

4. Centrifuge with cooling function

5. 96 well microplates

6. Microplate reader

\section{Procedure}

1. Plant or seed tissue (Arabidopsis thaliana) is weighed. Use about $100 \mathrm{mg}$ per extraction.

2. Tissues are ground to a fine powder in liquid nitrogen using a mortar and pestle. The tissue must be kept frozen during grinding.

3. Twice the fresh weight ( $w / v)$ of extraction buffer is added to the powder, and the powder allowed to thaw in the buffer.

4. Vortex for $10 \mathrm{sec}$.

5. Extracts are rotated at $4{ }^{\circ} \mathrm{C}$ for $30 \mathrm{~min}$ and centrifuged at $11,500 \times \mathrm{g}$ at $4{ }^{\circ} \mathrm{C}$ for $20 \mathrm{~min}$.

6. The supernatant is the soluble protein extract. Use fresh supernatants immediately for the PME enzyme assay, as the activity can be affected by freezing.

7. Four replicates of each sample (10 $\mu \mathrm{l}$ each) are pipetted into microplate wells. For the negative control, use protein extraction buffer only. For a positive control, use a solution of commercially available PME in protein extraction buffer.

8. Master mix $(180 \mu l)$ is added to each well and mixed by pipetting up and down. Avoid the formation of bubbles.

9. To start the reaction, add $10 \mu$ of the pectin solution to the samples, the negative and the positive control, but not to the background controls. Mix well by pipetting up and down.

10. Immediately put the plate into the microplate reader. If bubbles have formed during the mixing process, shake plate for $5 \mathrm{sec}$. Record the changes in absorption at $340 \mathrm{~nm}$ over 15 min at room temperature.

11. The change in absorption per unit time over the linear part of the reaction is calculated for each well, and used to calculate the increase in concentration of NADH. The NADH 
concentration is calculated using Lambert-Beer's law with the extincion coefficient $\varepsilon_{340}$ for $\operatorname{NADH}\left(6,220 \mathrm{M}^{-1} \mathrm{~cm}^{-1}\right)$. One nkat PME activity is defined as $1 \mathrm{nmol} \mathrm{NADH}$ formed per second.

12. The activities of the triplicates are averaged.

\section{$\underline{\text { Recipes }}$}

1. Protein extraction buffer

$100 \mathrm{mM}$ Tris- $\mathrm{HCl}(\mathrm{pH} 7.5)$

$500 \mathrm{mM} \mathrm{NaCl}$

$1 x$ protease inhibitor cocktail

2. Master Mix (per sample)

$20 \mu$ pectin solution

$2 \mu \mathrm{l}$ alcohol oxidase solution

$2 \mu \mathrm{l}$ formaldehyde dehydrogenase solution

$156 \mu \mathrm{I}$ NAD+ solution

\section{Acknowledgments}

This work was supported by the Swiss National Science Foundation (grant 31003A_127563; to TB) and by stipends to SB from the European Molecular Biology Organisation (EMBO: ALTF 61-2010) and the Leopoldina Fellowship Programme of the National Academy of Science Leopoldina (LPDS 2009-35).

\section{References}

1. Grsic-Rausch, S. and Rausch, T. (2004). A coupled spectrophotometric enzyme assay for the determination of pectin methylesterase activity and its inhibition by proteinaceous inhibitors. Anal Biochem 333(1): 14-18.

2. Mueller, K., Levesque-Tremblay, G., Bartels, S., Weitbrecht, K., Wormit, A., Usadel, B., Haughn, G. and Kermode, A. R. (2013). Demethylesterification of cell wall pectins in Arabidopsis plays a role in seed germination. Plant Physiol 161(1): 305-316.

3. Wolf, S., Mouille, G. and Pelloux, J. (2009). Homogalacturonan methyl-esterification and plant development. Mol Plant 2(5): 851-860. 